
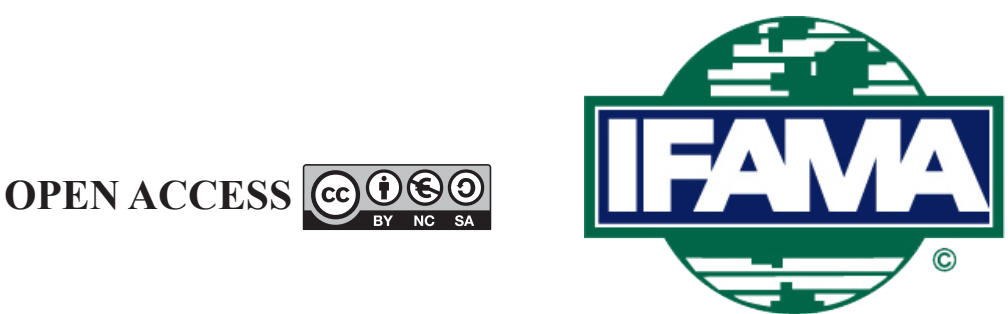

International Food and Agribusiness Management Review

Volume 24, Issue 4, 2021; DOI: 10.22434/IFAMR2020.0081

Received: 26 May 2020 / Accepted: 17 October 2020

Special Issue: Growth of agroholdings and mega-farms in transition and emerging market economies: institutional and organizational aspects

\title{
What drives the acquisition behavior of agroholdings? Performance analysis of agricultural acquisition targets in Northwest Russia and Ukraine RESEARCH ARTICLE
}

\author{
Igor Ostapchuk $^{\oplus a}$, Taras Gagalyuk ${ }^{\mathrm{b}}$, David Epshtein ${ }^{\mathrm{c}}$ and Abusupyan Dibirov ${ }^{\mathrm{d}}$ \\ ${ }^{a}$ Research Associate, ${ }^{b}$ Senior Researcher, Department of Structural Development of \\ Farms and Rural Areas, Leibniz Institute of Agricultural Development in Transition \\ Economies (IAMO), Theodor-Lieser-Strasse 2, 06120 Halle (Saale), Germany \\ ${ }^{c}$ Professor, ${ }^{d}$ Department Head, Department of Economic and Social Problems \\ of Agricultural Enterprises, North-West Institute for Agricultural Economics, \\ Podbelsky highway 7, 196608, St. Petersburg - Pushkin, Russian Federation
}

\begin{abstract}
This article provides pioneering empirical evidence on the selection of acquisition targets by agroholdings in transition economies. We use panel data from Ukraine and Northwest Russia covering the years 2005-2016. Binomial logistic regression models were estimated to analyze the impacts of farm capital strength, financial performance and size on the farm's likelihood of being acquired by an agroholding. Our results indicate that agroholding target selection considerations tend to change over time and have shifted from farm size to farm performance in both countries. However, agroholdings in both countries prefer to 'grab lemons', i.e. acquire poorly performing farms, but they differ with respect to target selection criteria. Agroholdings in Northwest Russia tend to focus on farm profitability, while their Ukrainian counterparts emphasize the capital structure of the target farms.
\end{abstract}

Keywords: acquisition target selection, agroholdings, Northwest Russia, pre-acquisition performance, Ukraine JEL code: G34, L25, Q14

\footnotetext{
(1)Corresponding author: ostapchuk@iamo.de
} 


\section{Introduction}

The development of so-called agroholdings in the agricultural sector of post-Soviet transition economies is a well-documented fact (Epstein et al., 2013; Gagalyuk, 2017; Rylko and Jolly, 2005; Serova, 2007). The term 'agroholding' appeared in the mid-2000s to designate a new type of large-scale farming operator that emerged and rapidly evolved in post-Soviet transition countries such as Kazakhstan, Russia and Ukraine. Generally, an agroholding is any entity consisting of a mother company that has control over dozens or hundreds of farms and operates dozens or even hundreds of thousands of hectares of farmland (Hermans et al., 2017). Along with a specialization in primary agriculture, i.e. crop and animal production, agroholdings include elements of vertical integration along multiple stages of the agri-food supply chain, such as the distribution of inputs, logistics, exports, food manufacturing and even food retail (Gagalyuk and Valentinov, 2019).

The rapid expansion of agroholdings largely came about through quick acquisitions of other standalone farms (Matyukha et al., 2015), while this process of farm takeovers itself became possible due to favorable access to outside capital facilitated by the extensive economic and political ties of agroholdings (Petrick et al., 2013; Visser et al., 2012; Wandel, 2011). In turn, larger sizes and the ability to benefit from economies of size were found to improve agroholdings' access to external sources of capital and, thus, to reinforce agroholdings' growth through acquisitions and investments in technologies (Gagalyuk, 2017). The concentration of market power and access to land were named as additional drivers of the farm acquisitions made by these large farming entities (Gagalyuk et al., 2018; Lapa et al., 2015).

Regarding agroholdings' ongoing involvement in acquisitive activities, several studies have questioned the economic viability of this sort of growth (Balmann et al., 2013; Epstein et al., 2013; Hahlbrock and Hockmann, 2012; Hockmann et al., 2009). It is, however, worth noting that these studies focused mainly on general performance analyses with a few unique examples of the post-acquisition performance of farms. At the same time, research on the pre-acquisition performance of farms and the actual role of that performance in farm acquisitions by agroholdings is still scarce. This is an important research gap because we still know little about how agroholdings choose acquisition targets, and this choice may significantly affect farm performance after the acquisition.

The theoretical literature on mergers and acquisitions (M\&A) puts forward three general hypotheses on firm motivations for M\&A. First, firm managers may use M\&A to maximize firm size or to 'build empires' (Mueller, 1969), with performance considerations being of secondary order in such decisions. Second, firms may want to shift their boundaries in order to exploit their own comparative advantage, and thus, they may choose less efficient acquisition targets ('grab lemons'). Third, firms may be seeking targets that have complementary efficiencies ('pick cherries') such that synergies between the firms can improve efficiency further (cf. Balsvik and Haller, 2010: 365).

Up-to-date anecdotal and case study evidence suggests that, in the early 2000s, agroholdings in Russia tended to build empires and grab lemons, and they were often impelled to do so because farms (and firms) were generally financially distressed due to the recent (1998) economic crisis. Moreover, in Russia, local authorities frequently requested agroholding owners to take over poorly performing farms (Matyukha et al., 2015; Visser et al., 2012). Anecdotal evidence from Ukraine indicates that the early acquisitive growth of agroholdings in the 2000s had little to do with performance considerations and was rather a result of a countrywide 'land rush' among high net-worth individuals who initially made their fortunes outside of agriculture (Lapa et al., 2015).

However, empirical findings from other industries show that firms can change their acquisition behavior over time due to various factors, such as prior acquisition experience, a change in market conditions or a change in institutional frameworks (Bebenroth and Chen, 2018; Chakrabarti and Mitchell, 2013). Quite a number of agroholdings in several post-Soviet countries have been and are still growing in the context of disruptive events associated with ongoing policy reforms, the global financial crisis (2008), the global food price 
crisis (2013) and local political conflicts (e.g. an ongoing conflict between Ukraine and Russia). Therefore, the extent to which this growth has been the result of an economic efficiency orientation is still a relevant question today. In the context of pre-acquisition performance research, this question can be formulated as follows: 'Do agroholdings 'pick cherries' by choosing to acquire higher-performing farms, or do they 'grab lemons' by targeting lower-performing farms? To what extent does the acquisition behavior of agroholdings change over time?'

Our study aims to answer this question by econometrically assessing the financial performance and capital strength of acquisition targets (standalone farms) in Northwest Russia and Ukraine prior to acquisition. We also corroborate the results of our quantitative analysis with a qualitative survey of agroholding managers. We use data from the Spark Interfax database, which contains approximately 172,000 farm-year observations with farm-level information on financial indicators from Northwest Russian and Ukrainian farms from 2005-2016. We estimate multiple binominal logistic regression models with an acquisition dummy as the dependent variable to test which factors affect the likelihood of farm acquisition. We further validate our results using in-depth interviews with managers of ten Ukrainian agroholdings.

Our analysis contributes to the existing literature on pre-acquisition performance in several ways. First, unlike most studies on pre-acquisition performance that focus on acquisitions within one country ${ }^{1}$ (e.g. Changqi and Ningling, 2010; Liu et al., 2017; Weche-Gelübcke, 2015), our research considers the pre-acquisition performance of farms in the context of two countries, Russia and Ukraine. This offers the possibility of a more in-depth understanding of the country-specific factors underlying acquisition target selection. Although Russia and Ukraine, as post-communist transition economies, have many commonalities, the agricultural sectors of both countries developed within different legal frameworks, especially with regard to agricultural factor markets such as the market for farmland (Nivievskyi and Romanovska, 2013). This can substantially affect the acquisition behavior of acquiring entities (Peng and Heath, 1996). Additionally, in Russia, we focus solely on the country's northwestern region due to the difficulty of accessing data for the whole country. It is common knowledge that climatic and soil conditions in Northwest Russia are less favorable for agricultural production than, e.g. the black soil regions in Russia or Ukraine. Therefore, a comparison between Northwest Russia and Ukraine can provide insights into the contingencies in farm acquisition strategies with respect to the production conditions.

Second, to the best of our knowledge, our study is the first to conduct an econometric analysis of preacquisition target selection in the sector of primary agriculture. Additionally, we use a longitudinal dataset that includes recent farm-level information. In this way, our research is able to complement and verify earlier case study evidence of agroholdings' farm acquisition behaviors.

The remainder of the paper is structured as follows. First, we describe our empirical setting, i.e. the agricultural sectors of Northwest Russia and Ukraine, with a particular focus on the development of agroholdings in these regions/countries. Second, we elaborate on the theoretical background of the pre-acquisition performance of firms. Third, we describe our methodology and data. Fourth, we present and discuss the results obtained. Finally, we draw conclusions.

\section{Agroholdings in Northwest Russia and Ukraine}

Agroholdings have developed through takeovers of standalone farms in both Russia and Ukraine (Gagalyuk, 2017; Matyukha et al., 2015). However, the establishment and proliferation of agroholdings took slightly different paths in the two countries.

\footnotetext{
${ }^{1}$ Studies by Pasiouras et al. (2007) and Damijan et al. (2015) could be considered notable exceptions in this respect. However, they use data from several EU countries with the sole purpose of constructing pooled datasets, and they do not conduct any cross-country comparisons. Our study does not allow for direct cross-country comparisons either, since we assess the models for Russia and Ukraine separately. However, our approach helps to extend the explanation of the acquisition determinants using country-specific factors such as legal frameworks, the institutional environment and related factor-market imperfections.
} 


\subsection{Development of agroholdings in (Northwest) Russia}

In the early stages of the transition toward the market economy, Russian agricultural producers faced problems in accessing capital, production inputs and output markets that led to the accumulation of huge debts and substantial reductions in farm efficiency. As a result, the government of the Russian Federation decided to mandate farm restructuring, enlargement and vertical integration (Rylko and Jolly, 2005). Local governments were given formal and informal instructions to promote the establishment of corporate holding structures in agriculture. In this way, the assets of indebted farms, which at that time were owned by workers and pensioners of former collective and state farms (Uzun et al., 2019), were merged together under the ownership of high net-worth individuals and business groups at the request of (and with the support of) local authorities (Matyukha et al., 2015; Visser et al., 2012).

However, initially, investor interest in agriculture was rather low due to low returns and persisting inefficiencies (Uzun et al., 2012). The farming sector became more attractive after the financial crisis of the late 1990s, when investors started searching for new opportunities in sectors that could offer stable returns with low risk. In the early 2000s, the Russian Tax Code was enacted. The Code created a preferential taxation regime for agriculture, according to which agricultural enterprises pay a flat agricultural tax of $6 \%$ on gross margins. Furthermore, the moratorium on farmland sales in Russia was lifted in 2003. Although the state obtained the preferential right to purchase farmland, this sort of liberalization led to growing numbers of land transactions, increased rentals and improved financing due to the possibility of using farmland as collateral. Accordingly, the efficiency of agricultural production improved (Nivievskyi and Romanovska, 2013). For example, in the early 2000s, the average profitability of grain production in Russia was higher than that of the oil industry (Serova, 2007). In the context of local governments' promotion of large-scale farming, barriers to the accumulation of larger land areas and the takeover of standalone farms' assets by holding and business group entities vanished (Visser et al., 2012).

As a result of these developments, the amount of land owned by legal entities in Russia grew from 5.0 million hectares in 2006 to 19.3 million hectares in 2018 (BEFL, 2019) ${ }^{2}$. Among those legal entities, the number of agroholdings whose sizes exceed 100,000 hectares increased from 30 in 2012 to 46 in 2018, while the land area they operate amounted to 13.5 million hectares in 2018 (Figure 1). As of 2018, the top 5 agroholdings in terms of land area controlled approximately 3.7 million hectares in total (BEFL, 2019). Regarding the role of agroholdings in Russia's agricultural production, Uzun et al. (2012) reported that all agroholdings together generated $15.4 \%$ of total agricultural output in 2011. In 2016, agroholdings accounted for more than $50 \%$ of sales and profits among all Russian agricultural enterprises (Uzun et al., 2019). Agroholdings are particularly active in vertically integrating crop and animal production as well as food processing. In 2016, their production shares in vertically integrated sectors such as pork, poultry and sugar accounted for 77,73 and $69 \%$, respectively (ibid).

The region of our focus, i.e. Northwest Russia, is characterized by similar dynamics. In a region that accounts for $4 \%$ of the country's total agricultural land (Table 1), 91\% of Northwest Russia's gross agricultural output is produced by legal entities, which is the highest share among all regions in Russia (Rosstat, 2019). Of those legal entities, the share of agroholdings in the total number of agricultural enterprises doubled from 2005 to 2016 (Table 2). In 2016, the shares of agroholdings in total revenue and the total value of fixed assets among agricultural enterprises were 57 and 47\%, respectively. At the same time, the disproportionately high share of sales relative to fixed assets demonstrates that agroholdings in Russia engage in a more intensive type of farming than non-agroholding farms do (Table 2). Uzun et al. (2019) observe similar trends in Russia as a whole. In addition, agroholdings actively develop vertical integration in sectors such as poultry, dairy and egg production in Northwest Russia (Dibirov and Moreva, 2019).

\footnotetext{
${ }^{2}$ According to the Federal Agency for the State Registration, Cadastre, and Cartography of Russia, the total area of agricultural land in the country
} exceeded 380 million hectares while land available for farming amounted to 197.8 million hectares as of January 1, 2018 (BEFL, 2019). 


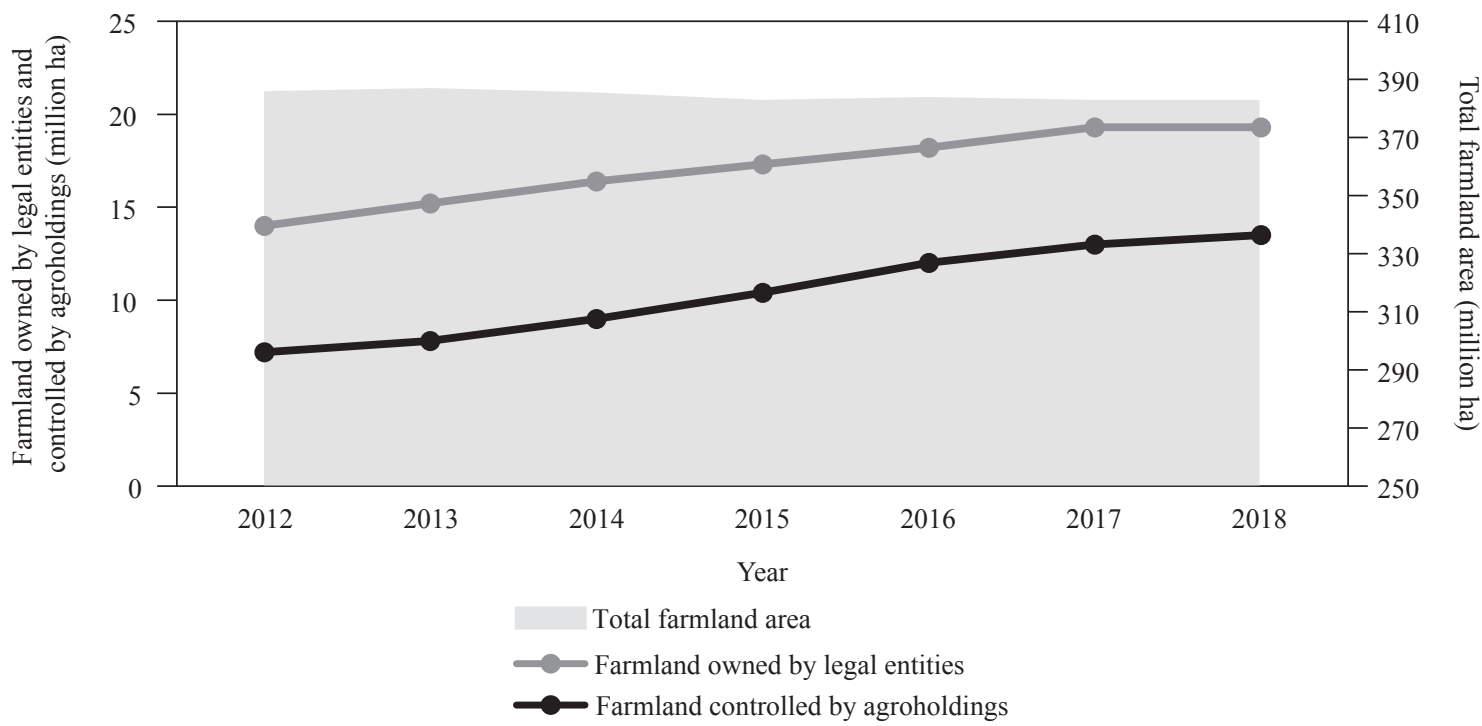

Figure 1. Farmland controlled by the largest agroholdings in Russia (above 100,000 hectares) in millions of hectares (BEFL, 2019).

Table 1. Role of Northwest Russia in the agriculture of the Russian Federation, 2018 (Rosstat, 2019).

\begin{tabular}{ll}
\hline Indicator & Share $\mathbf{( \% )}$ \\
\hline Agricultural production by legal entities & 91.4 \\
Agricultural land & 4.0 \\
Arable land & 2.5 \\
Sown areas & 1.7 \\
Potato production & 4.5 \\
Vegetable production & 3.6 \\
Number of cattle & 3.8 \\
Number of cows & 4.0 \\
Number of pigs & 7.6 \\
Cattle and poultry production & 6.8 \\
Milk production & 6.1 \\
Egg production & 9.8 \\
\hline
\end{tabular}

\subsection{Development of agroholdings in Ukraine}

In Ukraine, the first stage of agricultural and land reform allowed privatization certificates to be granted to the rural inhabitants that were formerly employed by kolkhozes and sovkhozes (Nivievskyi et al., 2015). These certificates entitled rural inhabitants to own shares in newly established farms, so-called collective agricultural enterprises that were formed as an intermediary in the transition from Soviet-type farms to fully privately owned farms. However, by the early 2000s, this type of farming proved incapable of operating under the conditions of the market economy. Linkages to input and output markets were broken, while the Ukrainian government heavily intervened in agricultural commodity markets. As a result, collective agricultural enterprises became highly indebted due to the financial crisis of 1997/98 (Lerman et al., 2007). 
Table 2. Revenue and fixed assets of agricultural enterprises in Northwest Russia (Spark Interfax, 2019). ${ }^{1}$

\begin{tabular}{|c|c|c|c|c|c|c|c|c|c|}
\hline \multirow[t]{2}{*}{ Year } & \multicolumn{3}{|c|}{ Agroholding farms } & \multicolumn{3}{|c|}{ Non-agroholding farms } & \multicolumn{3}{|c|}{ Share of agroholdings } \\
\hline & No. & $\begin{array}{l}\text { Revenue, } \\
\text { mn RUB }\end{array}$ & $\begin{array}{l}\text { Fixed assets, } \\
\text { mn RUB }\end{array}$ & No. & $\begin{array}{l}\text { Revenue, } \\
\text { mn RUB }\end{array}$ & $\begin{array}{l}\text { Fixed assets, } \\
\text { mn RUB }\end{array}$ & No. & $\begin{array}{l}\text { Revenue, } \\
\text { mn RUB }\end{array}$ & $\begin{array}{l}\text { Fixed assets, } \\
\text { mn RUB }\end{array}$ \\
\hline 2005 & 124 & $12,861.3$ & $8,948.1$ & 903 & $19,094.4$ & $23,889.7$ & $12 \%$ & $40 \%$ & $27 \%$ \\
\hline 2006 & 139 & $14,722.0$ & $11,692.0$ & 1,195 & $22,903.9$ & $26,325.2$ & $10 \%$ & $39 \%$ & $31 \%$ \\
\hline 2007 & 139 & $17,121.9$ & $14,585.4$ & 1,195 & $28,788.0$ & $30,550.2$ & $10 \%$ & $37 \%$ & $32 \%$ \\
\hline 2008 & 111 & $20,622.2$ & $18,409.1$ & 1,052 & $37,446.1$ & $38,001.8$ & $10 \%$ & $36 \%$ & $33 \%$ \\
\hline 2009 & 230 & $34,500.3$ & $25,398.1$ & 933 & $28,819.0$ & $40,146.9$ & $20 \%$ & $54 \%$ & $39 \%$ \\
\hline 2010 & 241 & $41,007.6$ & $33,830.6$ & 940 & $32,429.5$ & $46,018.0$ & $20 \%$ & $56 \%$ & $42 \%$ \\
\hline 2011 & 258 & $48,916.4$ & $50,083.7$ & 883 & $36,401.4$ & $63,808.1$ & $23 \%$ & $57 \%$ & $44 \%$ \\
\hline 2012 & 284 & $56,155.4$ & $65,574.2$ & 942 & $39,550.6$ & $81,109.9$ & $23 \%$ & $59 \%$ & $45 \%$ \\
\hline 2013 & 290 & $52,458.3$ & $66,739.0$ & 996 & $38,338.3$ & $71,043.5$ & $23 \%$ & $58 \%$ & $48 \%$ \\
\hline 2014 & 245 & $68,305.6$ & $68,746.9$ & 1,154 & $46,508.2$ & $84,373.1$ & $18 \%$ & $59 \%$ & $45 \%$ \\
\hline 2015 & 314 & $81,569.1$ & $80,001.7$ & 1,036 & $53,692.9$ & $79,278.7$ & $23 \%$ & $60 \%$ & $50 \%$ \\
\hline 2016 & 310 & $85,129.6$ & $74,473.3$ & 1,028 & $64,359.9$ & $83,027.5$ & $23 \%$ & $57 \%$ & $47 \%$ \\
\hline
\end{tabular}

${ }^{1}$ The official exchange rate as of the end of 2005 was: USD $1=$ RUB 28.78 .

Given the poor performance of the agricultural sector, Ukrainian government decided to implement the second stage of agricultural and land reform in the early 2000s. The Presidential Decree of 1999 wrote off all debts of collective agricultural enterprises and relieved them from all non-core social obligations that had been in place since Soviet times (Gagalyuk and Schaft, 2016).

In 2001, the Ukrainian Land Code, which recognized private farmland ownership, was adopted. Approximately 7 million rural inhabitants (former employees of kolkhozes and sovkhozes) became owners of land plots and obtained the right either to establish their own farms or to earn an income from renting out their plots to corporate farms, which are not allowed to own land. In addition, a moratorium on the purchase and sale of farmland was introduced and retained until January 2008 and then extended each year until the present day ${ }^{3}$. However, the Land Code did not limit the lease terms for farmland. As a result, very long-term leases led to a de-facto absorption of land into corporate equity. The moratorium thus enabled agroholdings to accumulate land through the lease of land plots from individual landowners and/or the acquisition of standalone farms if the growth in land was restricted by the long-term lease contracts between these standalone farms and individual landowners ${ }^{4}$ (Nivievskyi et al., 2015).

In addition, agricultural enterprises became subject to preferential taxation. They were granted the right to choose whether to be taxed by a flat agricultural tax (levied at a very low $0.15 \%$ on the government-imposed normative monetary value of the farmland in use) or to receive refunds on the value-added tax (VAT) (UCAB, 2011). These preferential, hectare-based and coupled taxes were among the main drivers of farm consolidation (Gagalyuk, 2017). In addition, approximately 20 Ukrainian agroholdings were able to raise capital through share offerings on international stock markets in the late 2000s, thus overcoming the problem of generally poor access to capital faced by Ukrainian enterprises on the local financial market (Gagalyuk et al., 2018).

\footnotetext{
${ }^{3}$ In spring 2020, a law on farmland turnover that will lift the moratorium on land sales in a stepwise manner from 2021 to 2024 was adopted by the Parliament of Ukraine (Verkhovna Rada of Ukraine, 2020).

${ }^{4}$ In fact, the latter is the land accumulation method preferred by agroholdings in the view of the lower transaction costs in accessing the land. In Ukraine, an average land plot owned by a rural inhabitant is approximately 4.2 hectares, while the average size of a (standalone) farm is approximately 2,000 hectares (State Statistics Service of Ukraine, 2019). Therefore, agroholdings prefer to access land via the acquisition of farms together with their land lease rights rather than via the conclusion of individual land lease agreements with rural inhabitants. We use the term 'standalone farms' to refer to legal entities that are not affiliated with agroholdings and that have established rental contracts with landowners (in the case of cropproducing farms).
} 
Favorable institutional conditions and access to capital enabled Ukrainian agroholdings to more than triple their operated farmland area since 2007, so that they now operate a total of 5.6 million hectares (Figure 2). At this scale, agroholdings account for $29 \%$ of the total farmland area used by corporate farms. Furthermore, agroholdings produce $59 \%$ of the total crop production value and $44 \%$ of total animal production value among corporate farms in today's Ukraine (UCAB, 2019). In 2016, the sales share of agroholdings among agricultural enterprises was $46 \%$, while they accounted for only $9 \%$ of all agricultural enterprises in the country (Table 3 ). This indicates that agroholdings in Ukraine engage in a more intensive type of farming relative to non-agroholding farms.

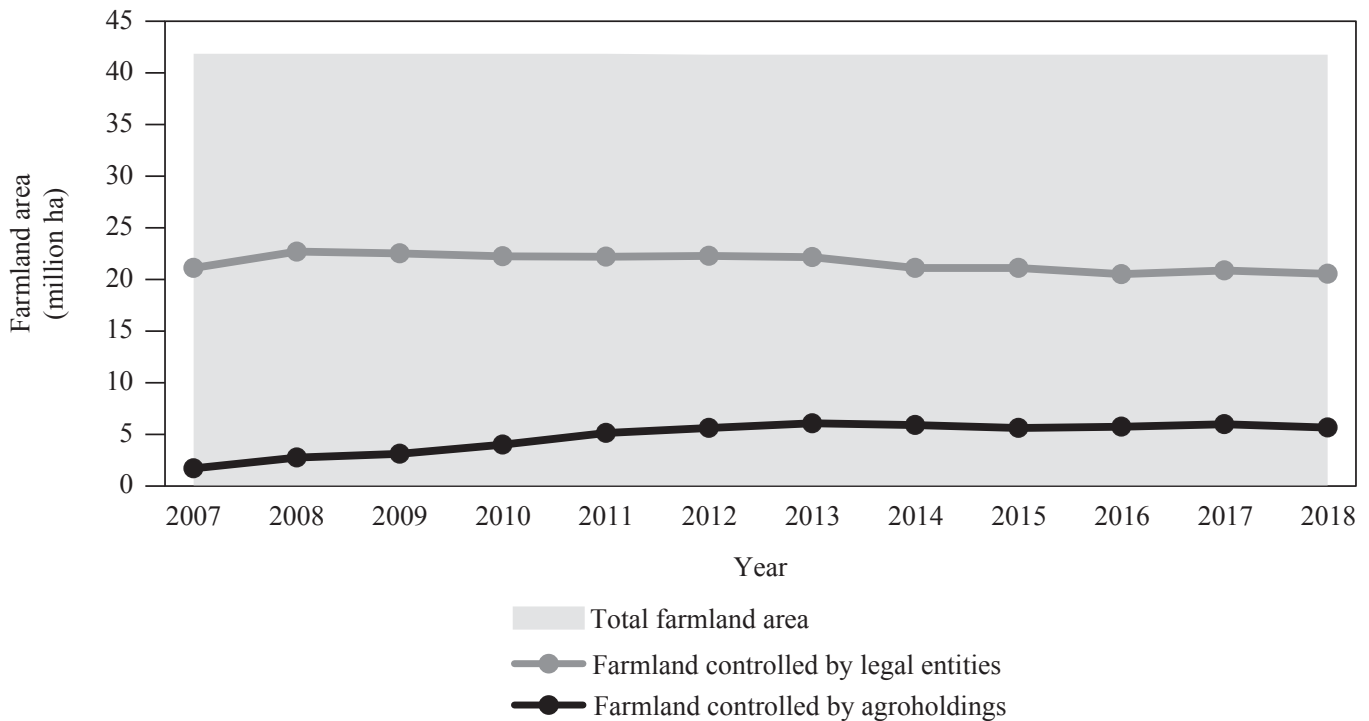

Figure 2. Farmland controlled by the largest agroholdings in Ukraine (above 10,000 hectares) in millions of hectares (UCAB, 2019).

Table 3. Revenue and fixed assets of agricultural enterprises in Ukraine (Spark Interfax, 2019). ${ }^{1}$

\begin{tabular}{|c|c|c|c|c|c|c|c|c|c|}
\hline \multirow[t]{2}{*}{ Year } & \multicolumn{3}{|c|}{ Agroholding farms } & \multicolumn{3}{|c|}{ Non-agroholding farms } & \multicolumn{3}{|c|}{ Share of agroholdings } \\
\hline & No. & $\begin{array}{l}\text { Revenue, } \\
\text { mn UAH }\end{array}$ & $\begin{array}{l}\text { Fixed assets, } \\
\text { mn UAH } \\
\end{array}$ & No. & $\begin{array}{l}\text { Revenue, } \\
\text { mn UAH }\end{array}$ & $\begin{array}{l}\text { Fixed assets, } \\
\text { mn UAH } \\
\end{array}$ & No. & $\begin{array}{l}\text { Revenue, } \\
\text { mn UAH }\end{array}$ & $\begin{array}{l}\text { Fixed assets, } \\
\text { mn UAH }\end{array}$ \\
\hline 2005 & 161 & $4,490.2$ & $1,580.3$ & 10,959 & $23,838.4$ & $20,641.2$ & $1 \%$ & $16 \%$ & $7 \%$ \\
\hline 2006 & 191 & $6,077.4$ & $2,317.8$ & 11,078 & $27,426.5$ & $21,676.8$ & $2 \%$ & $18 \%$ & $10 \%$ \\
\hline 2007 & 275 & $9,600.2$ & $3,585.8$ & 10,800 & $33,330.5$ & $21,651.9$ & $2 \%$ & $22 \%$ & $14 \%$ \\
\hline 2008 & 382 & $14,738.3$ & $5,729.0$ & 10,487 & $43,976.8$ & $23,691.8$ & $4 \%$ & $25 \%$ & $19 \%$ \\
\hline 2009 & 473 & $22,004.3$ & $7,709.4$ & 10,219 & $53,195.5$ & $28,256.5$ & $4 \%$ & $29 \%$ & $21 \%$ \\
\hline 2010 & 601 & $27,637.5$ & $9,647.8$ & 9,505 & $59,000.1$ & $25,545.9$ & $6 \%$ & $32 \%$ & $27 \%$ \\
\hline 2011 & 941 & $53,197.4$ & $16,982.4$ & 9,490 & $66,587.9$ & $28,624.4$ & $9 \%$ & $44 \%$ & $37 \%$ \\
\hline 2012 & 1,011 & $70,310.2$ & $21,142.3$ & 9,929 & $79,107.8$ & $33,818.4$ & $9 \%$ & $47 \%$ & $38 \%$ \\
\hline 2013 & 1,006 & $69,532.2$ & $24,880.6$ & 9,862 & $78,697.8$ & $38,326.4$ & $9 \%$ & $47 \%$ & $39 \%$ \\
\hline 2014 & 940 & $92,713.4$ & $26,414.2$ & 8,977 & $100,597.2$ & $39,752.3$ & $9 \%$ & $48 \%$ & $40 \%$ \\
\hline 2015 & 899 & $154,535.6$ & $27,034.6$ & 8,730 & $163,205.3$ & $44,733.1$ & $9 \%$ & $49 \%$ & $38 \%$ \\
\hline 2016 & 850 & $153,037.8$ & $34,294.1$ & 8,341 & $179,961.2$ & $54,848.3$ & $9 \%$ & $46 \%$ & $38 \%$ \\
\hline
\end{tabular}

${ }^{1}$ The official exchange rate as of the end of 2005 was: USD $1=$ UAH 5.05. 
Overall, agricultural policies driven by the objectives of self-sufficiency and an export orientation contributed at least in part to the rapid development of agroholdings in Russia and Ukraine. Unprecedented policy measures, such as debt waiving programs, low taxes and subsidized loans, combined with imperfections in land and capital markets were (and still are) among the drivers of this growth. In this context, from the perspective of both the political economy and farm management, it is important to understand the extent to which the growth of agroholdings is or can become economically viable over time. One way to fulfil this objective is to scrutinize the factors behind agroholdings' farm acquisitions, and the following section elaborates theoretically on this topic.

\section{Acquisition target selection (by agroholdings): literature overview}

The theoretical literature outlines two 'standard' modes of firm growth under market competition. The first is so-called 'organic' growth, whereby a firm grows through an efficient use of its own resources or due to an increase in the firm's market share as a result of growing demand for the firm's services and products (Davidsson and Delmar, 1997; Kim et al., 2011; Penrose, 1995). The alternative to organic growth is growth through M\&A, which involves expansion through the purchase (acquisition) of or unification (merger) with another firm (Palmer et al., 1993; Penrose, 1995). A primary focus of the present study is on the M\&A mode of growth and one particular aspect of that growth - firms' motivations and criteria for acquisition target selection.

Earlier studies in strategic management postulate that value creation through integration is a major motive for M\&A (Capron and Mitchell, 1997; Seth et al., 2000). However, insights gained from other related research domains suggest a more detailed view on the motivations for M\&A may be appropriate and propose three general hypotheses on firm involvement in M\&A activities.

First, as devised by agency theorists, involvement in M\&A may result from 'managerial hubris' (Balsvik and Haller, 2010). According to this view, firm managers may choose the M\&A growth strategy to maximize firm size or to build empires (Mueller, 1969). Efficiency considerations are of secondary concern in such decisions, and therefore, no clear predictions can be made as to whether the target firms are more likely to be high-performing ‘cherries' or poorly performing 'lemons' (cf. Balsvik and Haller, 2010: 365).

The second general motive for M\&A is management's comparative advantage. According to the neoclassical theory of the firm, firms may want to shift their boundaries (including across industries) in response to events that alter their and their competitors' comparative advantage (ibid). The possibility of value creation in such acquisitions depends mainly on the levels of inefficient management, i.e. the mismatch between a target firm's growth and the financial, labor and technological resources at its disposal (Agarwal and Jaffe, 2003; cf. Bebenroth and Chen, 2018: 12). Here, an acquiring firm 'grabs a lemon' and deploys its organizational capabilities to obtain the greatest marginal payoff by disciplining (or replacing) the target firm's management. The target's performance is, therefore, expected to increase after acquisition, in particular in terms of productivity and profitability (Maksimovic et al., 2013). However, acquirers may incur high transaction and integration costs during and after an acquisition, and thus, targets should have the potential to compensate for these costs in the future. Empirical evidence suggests that acquiring firms often place greater weight on expected costs relative to a specific acquisition than on the acquisition target's capabilities in handling the costs (Chakrabarti and Mitchell, 2013).

There is, however, an opposite motive for firms to engage in M\&A, namely, an endeavor to achieve synergistic effects. According to this view, acquiring firms are searching for cherries, i.e. targets that have complementary efficiencies such that synergies between firms can improve efficiency further (cf. Balsvik and Haller, 2010: 365).

Existing empirical studies on the abovementioned hypotheses generally produce mixed results. Depending on the empirical context, some of them find evidence of empire building (Aybar and Ficici, 2009; Gorton et 
al., 2009), others find that acquiring firms prefer to grab lemons (Bellak et al., 2006), and yet others observe 'cherry-picking' (Salis, 2008; Spearot, 2007) or, quite often, a mixture of cherry-picking and lemon-grabbing (Arndt and Mattes, 2010). With regard to agroholdings, the scant empirical evidence suggests that efficiency motivations for acquisitions were rare in the early stages of agroholding development.

For instance, in their political economy analysis of large-scale land acquisitions in post-Soviet Russia, Visser et al. (2012) pointed to pressure from local authorities on agroholdings to take over indebted farms. Matyukha et al. (2015), who analyzed the growth trajectories of agroholding-affiliated farms vis-à-vis their standalone counterparts in Russia, found only minor differences between the two groups. Any advantages held by affiliated farms were found to be due to strong positioning in local and regional markets and making the most of lobbying and ties to relevant politicians. At the same time, findings by Epshtein et al. (2013) pointed to a combination of the managerial hubris and efficiency rationales for agroholdings' expansion in Russia. They arrived at the conclusion that political economy factors alone could not explain the evolution of agroholdings; instead, a complex mix of political and pure economic factors nurtured agroholdings' development. As a result, the persistence of agroholdings cannot easily be reduced to rent seeking. Instead, agroholdings demonstrated good economic performance due to improvements in total factor productivity resulting from large investments in modern technology. However, these investments were mostly credit financed, and therefore, agroholding farms were found to be at higher risk of default than standalone farms.

Empirical evidence from Ukraine also points to the lack of efficiency considerations behind acquisition target selection by agroholdings. Balmann et al. (2013) found that agroholding-affiliated farms had higher yields than those of standalone farms due to higher production intensities. However, agroholding farms were not found to exhibit, on average, higher total factor productivity or higher profitability. Factors such as a lack of management skills, know-how and human capital as well as high adjustment and learning costs were named as potential reasons for productivity deficits among both the agroholdings and standalone farms. Lapa et al. (2015) demonstrated that agroholdings in Ukraine faced high transaction costs resulting from the need to link individual production units, i.e. individual affiliated farms. Some agroholdings were found to pay little attention to post-acquisition business optimization, as land accumulation was the primary goal of their expansion. To this end, Deininger et al. (2013) found that farms in Ukraine operated under constant returns to scale (based on the 2001-2012 data), thus pointing to the absence of the desired scale economies. Gagalyuk et al. (2018) showed that Ukrainian agroholdings bear higher labor and land lease costs than standalone farms.

However, firms can change or even combine their acquisition motivations over time due to factors such as prior acquisition experience, market dynamics or changes in institutional frameworks (Bebenroth and Chen, 2018; Chakrabarti and Mitchell, 2013). Over the last decade and a half, agriculture in Russia and Ukraine has experienced a number of shocks. The first was the 2008 financial crisis that heavily affected agricultural production and the related industries in both countries (Epstein et al., 2018). Second, as global breadbaskets, both countries were subject to the global food price crisis in 2013 (Götz et al., 2015; Ostapchuk et al., 2016). Third, the ongoing political conflict between Russia and Ukraine that began in 2014 has resulted in the introduction of Western sanctions on Russian businesses. The government of the Russian Federation responded by adopting a new food doctrine, which introduced a ban on food imports and strengthened the support for local agri-food producers (Wegren, 2014). The introduced food embargo also had consequences for producers in Ukraine since Russian agri-food markets had been one of the major destinations for Ukrainian exports (Nivievskyi et al., 2015).

Nevertheless, agroholdings in both Russia and Ukraine were able to continue their expansion in the context of these events (Section 2). Thus, in view of the growing turbulence in the business environment, the question remains as to the extent to which agroholdings' acquisitive growth is efficiency-oriented, and which factors drive this growth, i.e. do agroholdings 'pick cherries' or do they 'grab lemons' or do they do both? We further address this question empirically. 


\section{Methods and data}

\subsection{Methods}

We conduct quantitative and qualitative analyses to investigate the target selection behavior of agroholdings in Northwest Russia and Ukraine. Similar to studies on acquisition target selection (Balsvik and Haller, 2010; Bebenroth and Chen, 2018), our quantitative analysis aims to explore how a farm's capital strength and financial performance, as well as structural characteristics, affect its likelihood of being acquired (Table 4).

As discussed earlier, high indebtedness was an important driver of farm takeovers in the early 2000s (Visser et al., 2012). As a result, studies that examine the relation between firm acquisitions and capital strength (i.e. the inverse of high indebtedness coupled with sound liquidity) generally find a negative relationship, although it is not statistically significant in most cases (Pasiouras et al., 2007; Weche-Gelübcke, 2015). There are a few possible explanations for this finding, predominantly from the lemon-grabbing perspective. First, a lack of capital strength tends to attract buyers who can infuse capital into the acquired firms. Second, the acquisition price of a firm tends to decrease proportionally with its financial obligations. Third, acquirers may have skillful managers who are able to operate successfully with high leverage. Fourth, a reasonable level of financial leverage can be perceived as an indicator of the target's ability to access outside capital (Matemilola et al., 2013; Pasiouras et al., 2007).

The target's financial performance is relevant for acquiring firms in terms of evaluating both potential risks and synergies associated with an acquisition (Bebenroth and Chen, 2018). Earlier studies have shown the prevalence of cherry-picking over lemon-grabbing in target selection based on profitability considerations, although these findings were often context-specific (Chen and Su, 1997; Gioia and Thomsen, 2004). In general, low profitability of targets points to inefficiencies that may increase the cost of the target's integration (cf. Weche Gelübcke, 2012: 4).

Organizational size is another important factor in acquisitions, as it signals the availability of potential size economies and the possibility of accessing valuable assets such as human capital or technology (Bebenroth and Chen, 2018; Hannan and Freeman, 1984; Kaul and Wu, 2016). In addition, growing firms are more likely to attract highly qualified labor (Markman and Gartner, 2002). Furthermore, as shown above in the context of agroholdings, farm size may be an important factor in acquisitions in the case of managerial hubris. Especially at the land rush stage of agroholding development (Lapa et al., 2015), incentives for agroholding managers tended to be closely related to the size or growth in size of the agroholding rather than to its profits.

In line with most studies on pre-acquisition firm performance, the dependent variable of interest in our quantitative analysis is binary, namely, the change in a farm's ownership status from standalone to agroholdingaffiliated (Table 4). We therefore use multiple binomial logistic regressions to test our models (e.g. De Beule and Duanmu, 2012; Froese, 2013; Muehlfeld et al., 2011 for examples of the logistic regressions used in the M\&A target selection studies).

Our models are specified as follows:

$$
\begin{aligned}
A_{i, t+1}= & \beta_{0}+\beta_{1} L e v_{i, t}+\beta_{2} C L_{i, t}+\beta_{3} S_{w c i, t}+\beta_{4} S_{i n t i, t}+\beta_{5} N P M_{i, t}+\beta_{6} R O A_{i, t}+\beta_{7} r_{i, t}+ \\
& \beta_{8} F A_{i, t}+\beta_{9} T L E_{i, t}+\beta_{10} \operatorname{Spc}_{i, t}+\beta_{11} \operatorname{Reg}_{i, t}+\varepsilon_{i, t},
\end{aligned}
$$

where $\beta_{1}-\beta_{11}$ denote vectors of the respective coefficients; $\beta_{0}$, an intercept; and $\varepsilon$, an error term. The description of the variables is provided in Table 4. 
Table 4. Operationalization of variables used in the logistic regressions. ${ }^{1}$

\begin{tabular}{|c|c|c|c|c|}
\hline Theoretical construct & Variable name & Symbol & $\begin{array}{l}\text { Measurement } \\
\text { unit }\end{array}$ & Measure description \\
\hline Farm acquisition & $\begin{array}{l}\text { Acquisition dummy } \\
\text { (dependent variable) }\end{array}$ & $A_{i, t}$ & $0 / 1$ & $\begin{array}{l}\text { Dummy variable representing changes } \\
\text { in ownership status of farm } i \text { from } \\
\text { 'standalone' to 'holding-affiliated' in } \\
\text { period } t \text {. It equals one if a farm was } \\
\text { acquired and zero otherwise. }\end{array}$ \\
\hline \multirow[t]{4}{*}{ Farm capital strength } & Leverage & Lev & $\%$ & $\begin{array}{l}\text { Average value of and absolute change } \\
\text { in the ratio of a farm's total debts to } \\
\text { total assets. }\end{array}$ \\
\hline & Current liquidity ratio & $C L$ & $\%$ & $\begin{array}{l}\text { Average value of and absolute change } \\
\text { in the ratio of a farm's current assets to } \\
\text { current liabilities. }\end{array}$ \\
\hline & Working capital ratio & $s_{w c}$ & $\%$ & $\begin{array}{l}\text { Average value of and absolute change } \\
\text { in the ratio of a farm's working capital } \\
\text { (i.e. current assets minus current } \\
\text { liabilities) to total assets. }\end{array}$ \\
\hline & Interest coverage ratio & $s_{\text {int }}$ & $\%$ & $\begin{array}{l}\text { Average value of the ratio of a farm's } \\
\text { outstanding interest to total revenue. }\end{array}$ \\
\hline \multirow[t]{2}{*}{$\begin{array}{l}\text { Farm financial } \\
\text { performance }\end{array}$} & Net profit margin & $N P M$ & $\%$ & $\begin{array}{l}\text { Average value of and change in the } \\
\text { ratio of a farm's net profits to revenue. }{ }^{2}\end{array}$ \\
\hline & Return on assets & $R O A$ & $\%$ & $\begin{array}{l}\text { Average value of and absolute change } \\
\text { in the ratio of a farm's net profit to } \\
\text { assets. }\end{array}$ \\
\hline \multirow[t]{2}{*}{ Farm size } & Revenue & $R$ & $\begin{array}{l}1000 \mathrm{UAH} \\
\text { or RUB }\end{array}$ & $\begin{array}{l}\text { Average value of and absolute change } \\
\text { in the farm's income/revenue from } \\
\text { regular business activities. }\end{array}$ \\
\hline & Fixed assets & $F A$ & $\begin{array}{l}1000 \mathrm{UAH} \\
\text { or RUB }\end{array}$ & $\begin{array}{l}\text { Quartiles of absolute change in the } \\
\text { value of a farm's tangible assets } \\
\text { (property, equipment, machinery, etc.) } \\
\text { used for production. }\end{array}$ \\
\hline \multirow[t]{3}{*}{ Control variables } & Type of legal entity & $T L E$ & categorical & $\begin{array}{l}\text { Type of legal entity (e.g. LLC, JSC, or } \\
\text { cooperative). }\end{array}$ \\
\hline & Specialization & Spec & categorical & Major specialization of the farm. \\
\hline & Region & $\operatorname{Reg}$ & categorical & Region where the farm is located. \\
\hline
\end{tabular}

${ }^{1}$ Data on $\mathrm{s}_{\text {int }}$ and Spec for Ukraine are not available.

${ }^{2}$ Growth in net profit margins is coded as a dummy variable, where the variable equals 1 if the growth is positive, 0 - otherwise.

To capture the growth potential of target farms, we operationalized most of our independent variables not only as the averages of the respective financial indicators but also as the absolute growth in the value of these indicators within the respective time periods ${ }^{5}$. Additionally, some of the continuous variables (e.g. average leverage ratio and average working capital ratio) were transformed into categorical variables to represent groups defined by the quartiles of a particular indicator. This enables our analysis to also include the variables that are highly correlated with each other as well as to reveal possible nonlinear relationships between the dependent and categorical explanatory variables. To avoid multicollinearity caused by 'the

\footnotetext{
5 Growth rates and averages were not constructed for categorical variables since they are time-invariant. We excluded some measures from the model estimation due to possible multicollinearity among the regressors. For example, we excluded the average value of fixed assets, as it is highly correlated with the average value of revenue. Additionally, some of the variables were coded as categorical (mainly based on quartiles) to avoid multicollinearity or to improve the explanatory power of the model.
} 
dummy variable trap' (Hirschberg and Lye, 2001), we constructed the benchmark (reference) group as the group with the highest number of treated (acquired) observations for each categorical variable, against which the other groups defined by the same variable are compared. The detailed descriptive statistics of the variables are presented in Supplementary Tables S2 and S3.

The output of the regressions is presented in the form of odds ratios estimated for each variable. For example, the acquisition odds ratios for the groups of farms defined based on the optimality levels of the financial leverage ${ }^{6}$ indicator are estimated as follows:

$$
O R=\frac{\pi(1)}{1-\pi(1)} / \frac{\pi(0)}{1-\pi(0)},
$$

where $O R$ denotes the odds ratio; $\pi(1)$, the probability of acquisition for a farm with optimal leverage; and $\pi(0)$, the probability of acquisition for a farm with nonoptimal leverage. $\pi(1) / 1-\pi(1)$ refers to the odds of acquisition for a farm with optimal leverage, and $\pi(0) / 1-\pi(0)$ represents the odds of acquisition for a farm with nonoptimal leverage. Therefore, if the obtained odds ratio is greater than one, it should be interpreted as growth in the odds of being acquired by a certain percentage; and vice versa, if the odds ratio is less than one, then it represents a decline in the acquisition odds by the respective percentage.

We assessed separate models for each country in order to reveal the similarities and differences between the target selection patterns in Northwest Russia and Ukraine as well as across time periods. Based on the available data, we were able to identify the industry-level M\&A waves in Northwest Russia and Ukraine ${ }^{7}$. One reason to analyze acquisition target selection in different time periods is the possibility of revealing commonalities and differences between the periods and in relation to an M\&A wave. Having an insufficient number of observations in individual years to run separate regressions is another reason, which is exactly the case with our data. Although there is no general agreement on the method for identifying M\&A waves, earlier studies have shown that M\&A tend to cluster in time during M\&A waves due to various shocks of a technological, economic or regulatory nature and/or due to behavioral factors (Harford, 2005; Maksimovic et al., 2013).

Thus, we identified industry-level M\&A waves as the years during which the ratio of acquired to total farms was higher than the average ratio for the entire period of analysis. This resulted in the identification of the M\&A wave that took place in 2009-2012 in both Northwest Russia and Ukraine. During this period, the number of holding affiliates increased substantially in both countries due to frequent farm acquisitions (Table 5). The number of acquisitions was 3-4 times larger than in the pre- and post-wave periods (2005-2008 and 2013-2016, respectively). Additionally, we validated the presence of the M\&A wave using regression analysis (Supplementary Table S1). The regression results showed the highest log-odds for acquisitions during 2009-2012 and thus supported the initial conclusion that this period represents an M\&A wave. Hence, in line with the M\&A literature, the substantial growth in the number as well as in the likelihood of acquisitions suggests the presence of an M\&A wave.

Thus, the models described above explain the differences in farm acquisition likelihoods during the M\&A wave (2009-2012) and the post-wave period (2013-2016). The independent variables from 2005-2008 explain the differences obtained in 2009-2012, while the independent variables from 2009-2012 explain the outcomes of 2013-2016.

The purpose of our qualitative analysis is to gain additional insights into the acquisition behavior of agroholdings that could not be captured through quantitative analysis. Our qualitative approach involves ten in-depth interviews with top managers of randomly selected Ukrainian agroholdings representing

\footnotetext{
6 'It is generally believed that the optimal level of the debt to assets ratio is 40-60\%.' (Li and Zhang, 2017: 116). We treat the values below and above the optimal level as low and high, respectively.

${ }^{7}$ To the best of our knowledge, previous research has not provided any information on M\&A waves in the agriculture of either country.
} 
Table 5. Holding-affiliated farms, revenues, and fixed assets in Northwest Russia and Ukraine. ${ }^{1,2}$

\begin{tabular}{|c|c|c|c|c|c|c|c|c|}
\hline \multirow[t]{2}{*}{ Period } & \multicolumn{4}{|c|}{ Northwest Russia } & \multicolumn{4}{|l|}{ Ukraine } \\
\hline & $\begin{array}{l}\text { AVG } N \text { of } \\
\text { affiliated } \\
\text { farms }\end{array}$ & $\begin{array}{l}\text { Total } N \text { of } \\
\text { acquired } \\
\text { farms }\end{array}$ & $\begin{array}{l}\text { AVG } \\
\text { revenue, } \\
\text { mn RUB }\end{array}$ & $\begin{array}{l}\text { AVG fixed } \\
\text { assets, mn } \\
\text { RUB }\end{array}$ & $\begin{array}{l}\text { AVG N of } \\
\text { affiliated } \\
\text { farms }\end{array}$ & $\begin{array}{l}\text { Total } N \text { of } \\
\text { acquired } \\
\text { farms }\end{array}$ & $\begin{array}{l}\text { AVG } \\
\text { revenue, } \\
\text { mn UAH }\end{array}$ & $\begin{array}{l}\text { AVG fixed } \\
\text { assets, mn } \\
\text { UAH }\end{array}$ \\
\hline 2005-2008 & 128 & $\mathrm{n} / \mathrm{a}$ & 16,332 & 13,409 & 252 & 225 & 8,727 & 3,303 \\
\hline 2009-2012 & 253 & 97 & 45,145 & 43,722 & 757 & 749 & 43,287 & 13,870 \\
\hline 2013-2016 & 290 & 28 & 71,866 & 72,490 & 924 & 189 & 117,455 & 28,156 \\
\hline
\end{tabular}

${ }^{1}$ Official exchange rates as of the end of 2005 were: USD 1 = RUB 28.78; USD 1 = UAH 5.05.

${ }^{2} \mathrm{AVG}=$ average; $\mathrm{N}=$ number.

different size categories and farm acquisition frequencies. The farmland area in operation for the interviewed agroholdings ranges from 40,000 hectares to 500,000 hectares, while the average area of operation is 190,000 hectares. The surveyed agroholdings control 184 farming enterprises in Ukraine. The sample includes three agroholdings that rarely acquire other farms, i.e. once per several years; four agroholdings that used to acquire farms actively earlier, i.e. conducted several acquisitions per year but have paused acquisitions in recent years; and three agroholdings that continued acquiring one or more farms actively in recent years. Three of the ten surveyed agroholdings also have experience running a farming business in Russia. The interviews were conducted in December 2019.

\subsection{Data}

For our quantitative analysis, we use the longitudinal datasets provided by the Spark Interfax database (Spark Interfax, 2019) to test the determinants of target selection for acquisition by agroholdings in Ukraine and Russia. These datasets contain farm-level financial reporting information in the form of balance sheets and profit-and-loss statements for the period 2005-2016. In particular, the financial reporting data for Ukrainian farms consist of 159,800 farm-year observations, while 12,100 farm-year observations are available for Northwest Russia. The Spark Interfax data for Ukrainian farms were cross-checked with the information on farm affiliations with agroholdings provided by the Association 'Ukrainian Agribusiness Club' and the YouControl database (YouControl, 2019). Information on farm affiliations with agroholdings for the Russian data was obtained from the Spark Interfax data on farm ownership. More specifically, in the Russian case, we considered a farm an agroholding affiliate if its controlling stake (more than 50\%) belonged to a different legal entity involved in agricultural production or a human person who owns controlling stakes in numerous farms or if a farm itself owned a controlling stake in another farm (also Uzun et al., 2008, 2019 for the identification methodology for farm agroholding affiliation).

The original datasets were cleaned and deflated to eliminate the effects of outliers and inflation. The cleaning procedure included dropping observations with missing values and those with extremely high values that were identified using histogram and scatter plot analyses. The deflation was carried out using the cumulative producer price indices for agricultural products, industrial products and services.

\section{Results and discussion}

\subsection{Quantitative analysis of the factors affecting farm acquisitions}

\section{- Model fit}

We tested our model specifications for multicollinearity by using correlation matrices and estimating variance inflation factors (VIFs). According to the tests, our estimations are not biased by multicollinearity. In the Ukrainian (Northwest Russian) models, the highest correlation coefficient was 0.59 (0.66), and the highest 
VIF was 4.8 (5.1), which is below the commonly used threshold of 0.7 for correlation and 10 for VIFs (Dormann et al., 2013; Hair et al., 1998). We describe the results of our logistic regressions in greater detail below. For the detailed results of the model estimations, see Supplementary Table S4.

\section{- The effects of capital strength}

Among the indicators for capital strength, farm indebtedness is particularly noteworthy, as it has been named as a major factor in the farm acquisitions made by agroholdings in earlier studies (Visser et al., 2012; Wandel, 2011). In this context, our results demonstrate that Northwest Russian farms whose leverage ratio was high - at a level between 60-100\% - indeed had higher odds of being acquired during the M\&A wave (2009-2012) than the benchmark (reference) group. The acquisition odds ratios for farms with other leverage ratios had statistically insignificant differences from the benchmark group. In contrast, indebted farms had lower acquisition odds ratios in Russia in the post-wave period (2013-2016). Namely, farms with a leverage ratio of 40-60\%, which is considered to be optimal (Li and Zhang, 2017), had 85\% lower acquisition odds ratios than the benchmark group (Supplementary Table S4). Other farms with both lower and higher leverage ratios had statistically insignificant differences in acquisition odds ratios.

These findings suggest that the tendency of Northwest Russian agroholdings to focus solely on financially distressed targets seems to have vanished over time. Moreover, another finding indicates that financially strong farms have become attractive acquisition targets: the effect of the interest coverage ratio was statistically significant in the post-wave period, although it was insignificant during the M\&A wave period. More specifically, an increase in the average value of this indicator of $1 \%$ led to an $12 \%$ increase in the acquisition likelihood in 2013-2016, which is significant at the 1\% level (Supplementary Table S4). This shows that the acquirers started choosing financially healthy targets (those able to repay their debts), a result that extends the existing evidence on farm acquisitions in Russia.

In Ukraine, the relationship between the leverage ratio and acquisitions was more linear: highly indebted farms had a higher likelihood of being acquired during the M\&A wave as well as in the post-wave period. The farms with leverage ratios that were lower than the ratios of the benchmark group had $40 \%$ lower acquisition odds during the M\&A wave period. Thus, Ukrainian agroholdings preferred to acquire financially weak 'lemons' throughout the period of observation.

\section{- The effects of financial performance}

We operationalized the financial performance of farms by net profit margin and return on assets (ROA). In Northwest Russia, the effect of the average values of net profit margins was statistically insignificant during the M\&A wave. In the post-wave period, higher average profit margins were associated with lower odds of farm acquisition. Regarding changes in net profit margins, we observed that growth in net profit margins led to $66 \%$ lower odds of acquisition during the M\&A wave. In the post-wave period, the effect of net profit growth on farm acquisition was not statistically significant (Supplementary Table S4). These findings generally suggest that more profitable Northwest Russian farms are less likely to be acquired.

Our estimations with respect to the ROA of Northwest Russian farms offer a somewhat deeper insight into the effects of financial performance on acquisition target selection. We observe that the farms with low and high ROA averages had significantly lower odds of being acquired during the M\&A wave than farms in the benchmark category (positive ROA). However, this pattern changed in the post-wave period. Highly unprofitable 'lemons' became significantly more likely to be acquired (at the 5\% significance level). At the same time, highly profitable farms also became attractive targets but to a lesser extent than unprofitable ones (at the 10\% significance level). On reflection, these findings together indicate a shift toward a greater efficiency orientation in the process of selecting acquisition targets over time, although 'cherries' are still less likely to be taken over. Thus, acquisition decisions in Northwest Russia tend to be driven by the comparative advantage rationale. 
In the Ukrainian sample, the effects of both the average value of and growth in profit margins were statistically insignificant in both periods. The farms with a low ROA were less likely to be acquired during the M\&A wave. In the post-wave period, the effects of ROA on farm acquisitions were insignificant (Supplementary Table S4). Generally, profitability was not found to be a decisive factor in acquisition target selection in Ukraine.

\section{- The effects of farm size and growth}

Our results show that the importance of farm size and growth as factors in farm acquisitions diminishes over time in both Northwest Russia and Ukraine. Larger revenues had a significant effect on the likelihood of being acquired during the M\&A wave in both countries. In the post-wave period, this effect was less pronounced. In line with the results obtained for the capital strength and financial performance constructs, this finding suggests a greater orientation toward performance and away from size among acquiring agroholdings. In addition, several other factors may come into play.

One such factor may be the price of acquisition, as it is generally associated with target size. To this end, our results demonstrate that larger and growing values of fixed assets were associated with a reduced likelihood of farm acquisition in Ukraine in both periods. In Northwest Russia, the effect of fixed assets on acquisitions was generally insignificant during the M\&A wave. In the post-wave period, growing asset values had a negative effect on the acquisition likelihood. Overall, the acquirers in both countries tended to refrain from selecting targets with large asset endowments.

\subsection{Qualitative analysis of acquisition target selection in Ukraine}

The results of the in-depth interviews with the managers of Ukrainian agroholdings demonstrate that the choice to expand via acquisitions is largely a consequence of the country's legal framework. The moratorium on farmland sales complicates organic growth and exploitation of scale economies, as there is a need to manage huge numbers of individual land rental contracts. Thus, it is easier to acquire standalone farms with already consolidated land.

Acquisition target selection in agroholdings is centralized but at a low degree of formalization. The interviewed managers argue that they have a general understanding of the characteristics that make a target attractive. Therefore, there is no need to formalize target selection, especially due to the uniqueness of each particular acquisition case. The level of target attractiveness is evaluated by assigned key specialists based on a range of indicators that measure the target's strengths and weaknesses in land management and agronomic practices, as well as the availability of machinery, equipment, warehouses, grain-hoppers, etc. The final decision is made by a major shareholder if an agroholding is locally owned or by the board of directors if there is foreign ownership.

The very high profitability of cash crops until 2012 was another factor in farm acquisitions that allowed agroholdings to put less effort into the post-acquisition integration of acquired farms. The other characteristics of the targets were of lower importance at that time, while many agroholdings were in their rapid formation and growth stages. Very often, agroholdings had little idea of where/in which regions they would end up forming their production clusters of appropriate size for a reasonable price. Therefore, they first acquired the farms that were available for purchase in different regions while planning to exchange them later for farms in locations that allow production clustering.

All managers of the agroholdings that have continued acquiring farms argue that the approaches to target selection have changed and become more sophisticated over the past 5-10 years. While the price of an acquisition remains the most important factor, agroholdings currently place somewhat greater emphasis on farm logistics infrastructure and the possibility of exploiting size economies. Most often, agroholdings choose to acquire financially distressed farms, and the primary reason for this is the lower acquisition price. Managers believe that farms usually become distressed because of poor management, a problem that can 
be solved relatively easily by appointing professional managers and introducing the agroholding's own production systems and management procedures.

Additionally, managers explain that the ideal target should be large and should be located close to the existing production facilities of the agroholding. Small targets may be attractive only if they are located close to the existing production facilities so that newly acquired land could be efficiently integrated into available land operations. The managers of the agroholdings that are less than 150,000 hectares in size mention that their companies plan to continue growing, and they also consider acquiring large farms located far from existing production clusters. In such a case, the aim would be to form another cluster in a new location. However, small and distantly located targets are not attractive to agroholdings.

Despite their growing role in target selection, factors such as soil fertility, infrastructure, the availability of storage facilities, farm reputation, and production structure similarities are of moderate importance. The availability of qualified employees is also moderately important, but large agroholdings of more than 250,000 hectares, as well as agroholdings that continue growing actively via M\&A, value this factor more highly. In addition, the fit of a target's production structure tends to increase in importance with the size of the acquirer.

Good financial reports, profitability and the efficiency of production were reported to be of low relevance in the process of selecting acquisition targets. Rather, the availability of financial and accounting documentation in general is important. Our respondents explain that (1) better performing targets are more expensive; and (2) one cannot be fully sure that reports represent reality. At the same time, the managers of larger agroholdings (those of more than 250,000 hectares) argue that sound financial reporting of targets is important for their companies.

Last but not least, managers highlight the importance of three additional factors. First is the role of climate and precipitation in the production process: there are regions with very good soil, but production is highly risky due to insufficient precipitation as a result of climate change. Second, not only does the size of the farm matter but also whether the land plots are consolidated, i.e. located next to or close to each other. Third, targets should not have abundant assets unrelated to production such as unused buildings, old hangars or fish ponds. One of our respondents referred to a case where a target farm had even owned a church and paid a salary to the priest.

\section{Conclusions}

The aim of this study was to deepen our understanding of the drivers of farm acquisitions by agroholdings. Motivated by earlier studies on this matter, which pointed to the significant role of noneconomic motivations in acquisitions in post-Soviet transition countries (e.g. Lapa et al., 2015; Visser et al., 2012), we attempted to explore the extent to which the agroholdings in Northwest Russia and Ukraine consider performance-related factors in their ongoing acquisitive activity. In addition, we sought to determine whether the agroholdings' acquisition behavior changes over time and whether there are notable differences rooted in the context of a particular country.

We found that earlier stages of agroholding development were indeed characterized by expansionary motives, while performance considerations were of less importance, especially during the M\&A wave of 2009-2012. This wave occurred just between two disruptive events that affected the agricultural sectors of Russia and Ukraine - the financial crisis of 2008 and the food price crisis of 2013. Most likely, the 2008 financial crisis enabled less expensive acquisitions and inflows of capital to agriculture due to decreasing margins in other industries. Moreover, based on the results of our interviews with agroholding managers, acquisitive agroholdings generally paid little attention to the performance of potential targets at that time due to the enormously high profitability of agricultural production. However, the 2013 global food price decline led to a decrease in margins in agriculture. This resulted in a slowdown of M\&A activities and reconsideration of acquisition approaches by agroholdings. 
Agroholdings would definitely like to continue taking over large farming entities at a reasonable price, but an unfavorable market situation impels them to consider factors such as capital strength, profitability and the location of the target farms. In Ukraine, however, targets' profitability plays a minor role, while particular characteristics such as consolidated farmland and competence in managing land rental contracts (related to the absence of a full-fledged land market) are also important.

Regarding the performance considerations behind target selection, our results suggest that agroholdings in both countries prefer 'lemons' over 'cherries' (although agroholdings in Northwest Russia demonstrate some tentative 'cherry-picking'). Among other things, the prevalence of 'lemon-grabbing' behavior implies that agroholdings were able to gain the necessary knowledge and management capabilities from previous acquisitions for post-acquisition farm integration. However, this statement requires further investigation with a particular focus on the post-acquisition performance of farms acquired by agroholdings.

Our results partly allow for differentiation between the Northwest Russian and Ukrainian cases with regard to the type of capabilities agroholdings deployed in acquisition target selection. In Ukraine, agroholdings put a heavier emphasis on the capital structure of the acquired farms than on their financial performance. A preference for highly indebted and, at the same time, low-asset-value targets requires sound financial management capabilities. In contrast, agroholdings in Northwest Russia tend to pay attention to targets' profitability, which underscores the importance of production and marketing competencies. However, our findings do not allow for further in-depth conclusions in this regard due to the absence of farm production information in our datasets.

Another issue associated with data limitations is the comparison of a whole country, Ukraine, with just one nonblack soil region in Russia. Secondary data point to a potential bias that can arise from comparing two different regions in terms of area and climatic and soil conditions. Tables 2 and 3 demonstrate that the agroholdings' (as well as non-agroholdings') sales-to-assets ratio in Ukraine is substantially higher than that in Northwest Russia. This may be due not only to worse conditions for agricultural production in Northwest Russia but also to the distinctive business models that agroholdings adopt. For instance, in view of the unfavorable conditions for crop production, Northwest Russian agroholdings may specialize in capitalintensive practices, e.g. animal production. Again, we are not able to make any further in-depth conclusions in this regard due to the lack of production data.

Accordingly, future research would benefit from comparing more homogenous regions in terms of production conditions, as well as from using production data. Among other things, this would enable a broader view of pre-acquisition target performance, including aspects such as total factor productivity and farm specialization. Another important step for future research on M\&A in the agriculture of transition economies is the assessment of the post-acquisition performance and integration processes of agroholding farms (and vertically integrated farms). The results of such research would substantially add to our understanding of the acquisition behavior of agroholdings and the developments in agricultural M\&A markets.

\section{Supplementary material}

Supplementary material can be found online at https://doi.org/10.22434/IFAMR2020.0081

Table S1. The likelihood of farm acquisition by year, log-odds.

Table S2. Descriptive statistics of the Northwest Russian sample used in logistic regressions.

Table S3. Descriptive statistics of the Ukrainian sample used in logistic regressions.

Table S4. Estimation results, odds ratios. 


\section{Acknowledgements}

This research was supported by the International Competence Center on Large Scale Agriculture (LaScalA) funded by the Leibniz Association (Germany). The authors are grateful to Dr. Jarmila Curtiss for helpful support on an earlier draft of the paper. The authors highly acknowledge two anonymous referees and the Editor of this journal for their helpful suggestions to improve the manuscript. The authors thank YouControl, the analytical system for compliance, market analysis, business intelligence, and investigations, for providing access to their system.

\section{References}

Agarwal, A. and J. Jaffe. 2003. Do takeover targets underperform? Evidence from operating and stock returns. Journal of Financial and Quantitative Analysis 38(4): 721-746.

Arndt, C. and A. Mattes. 2010. Cross-border mergers and acquisitions of multinational firms. New firm-level evidence. Discussion paper, IAW, Tübingen, Germany.

Aybar, B. and A. Ficici. 2009. Cross-border acquisitions and firm value: an analysis of emerging-market multinationals. Journal of International Business Studies 40(8): 1317-1338.

Balmann, A., J. Curtiss, T. Gagalyuk, V. Lapa, A. Bondarenko, K. Kataria and F. Schaft. 2013. Productivity and efficiency of Ukrainian agricultural enterprises. Agriculture policy report, German-Ukrainian Agricultural Policy Dialogue, Kyiv, Ukraine. Available at: https://apd-ukraine.de/images/APD APR_06-2013_Efficiency_eng.pdf

Balsvik, R. and S.A. Haller. 2010. Picking 'lemons' or picking 'cherries'? Domestic and foreign acquisitions in Norwegian manufacturing. Scandinavian Journal of Economics 112(2): 361-387.

Bebenroth, R. and P.-L. Chen. 2018. Cherry picking versus lemon grabbing: target selection of cross-border and domestic acquisitions in Japan. Discussion Paper, Research Institute for Economics and Business Administration, Kobe University, Japan.

BEFL. 2019. Russia's largest agricultural landholders 2019. BEFL, Moscow, Russian Federation.

Bellak, C., M. Pfaffermayr and M. Wild. 2006. Firm performance after ownership change: a matching estimator approach. Applied Economics Quarterly 52(1): 29-54.

Capron, L. and W. Mitchell. 1997. Bilateral resource redeployment and capabilities improvement following horizontal acquisitions. Industrial and Corporate Change 7(3): 453-484.

Chakrabarti, A. and W. Mitchell. 2013. The persistent effect of geographic distance in acquisition target selection. Organization Science 24(6): 1805-1826.

Changqi, W. and X. Ningling. 2010. Determinants of cross-border merger \& acquisition performance of Chinese enterprises. Procedia Social and Behavioral Sciences 2: 6896-6905.

Chen, C., and R. Su. 1997. Do cross-border acquisitions of US targets differ from US domestic takeover targets? Global Finance Journal 8(1): 71-82.

Damijan, J., C. Kostevc and M. Rojec. 2015. Growing lemons or cherries? Pre- and post-acquisition performance of foreign-acquired firms in new EU member states. The World Economy 38(4): 751-772.

Davidsson, P. and F. Delmar. 1997. High-growth firms: characteristics, job contribution and method observations. Paper presented at RENT XI Conference. November 27-28, 1997. Mannheim, Germany.

De Beule, F. and J.L. Duanmu. 2012. Locational determinants of internationalization: a firm-level analysis of Chinese and Indian acquisitions. European Management Journal 30(3): 264-277.

Deininger, K., D. Nizalov and S.K. Singh. 2013. Are mega-farms the future of global agriculture? Exploring the farm size-productivity relationship. Policy Research Working Paper Series 6544, The World Bank, Washington, DC, USA.

Dibirov, A. and A. Moreva. 2019. Theoretical foundations of sustainable integration in meat sector of a region. Innovations 1(243): 57-66. (in Russian)

Dormann, C.F., J. Elith, S. Bacher, C. Buchmann, G. Carl, G. Carré, J.R. García Marquéz, B. Gruber, B. Lafourcade, P.J. Leitão, T. Münkemüller, C. McClean, P.E. Osborne, B. Reineking, B. Schröder, A.K. Skidmore, D. Zurell and S. Lautenbach. 2013. Collinearity: a review of methods to deal with it and a simulation study evaluating their performance. Ecography 36(1): 27-46. 
Epstein, D., J. Curtiss, T. Gagalyuk and I. Unay Gailhard. 2018. The factors of resilience of agricultural enterprises against external shocks. Problems of Economic Transition 60(12): 883-906.

Epstein, D., K. Hahlbrock and J. Wandel. 2013. Why are agroholdings so pervasive in Russia's Belgorod oblast'? Evidence from case studies and farm-level data. Post-Communist Economies 25(1): 59-81.

Froese, H.G. 2013. Predicting takeover targets. An empirical analysis of the European market. MSc-thesis, University of St. Gallen (HSG), St. Gallen, Switzerland.

Gagalyuk, T. 2017. Strategic role of corporate transparency: the case of Ukrainian agroholdings. International Food and Agribusiness Management Review 20(2): 257-277.

Gagalyuk, T. and F. Schaft. 2016. Corporate social responsibility in agribusiness. Agriculture policy report, German-Ukrainian Agricultural Policy Dialogue, Kyiv, Ukraine. Available at: https://apd-ukraine. de/images/APD_APR_08-2016_CSR_in_Ukrainian_agriculture_eng.pdf

Gagalyuk, T. and V. Valentinov. 2019. Agroholdings, turbulence, and resilience: the case of Ukraine. Journal of East European Management Studies 24(3): 484-496.

Gagalyuk, T., V. Valentinov and F. Schaft. 2018. The corporate social responsibility of Ukrainian agroholdings: the stakeholder approach revisited. Systemic Practice and Action Research 31(6): 675-698.

Gioia, C. and S. Thomsen. 2004. International acquisitions in Denmark 1990-1997: selection and performance. Applied Economics Quarterly 50(1): 61-87.

Gorton, G., M. Kahl and R.J. Rosen. 2009. Eat or be eaten: a theory of mergers and firm size. The Journal of Finance 64(3): 1291-1344.

Götz, L., U. Koester, T. Glauben and R. Bulavin. 2015. The rouble crisis and Russian wheat export controls. Intereconomics - Review of European Economic Policy 50(4): 227-233.

Hahlbrock, K. and H. Hockmann. 2012. Does group affiliation increase productivity and efficiency in Russia's agriculture? Evidence from agroholdings in the Oblast Belgorod. In: E.G. Yasin (ed.) Proceedings of the $12^{\text {th }}$ International Scientific Conference on Problems of Economic and Societal Development. Higher School of Economics, Moscow, Russian Federation, pp. 100-109.

Hair, J.F., Black, W.C., Babin, B.J., Anderson, R.E. and Tatham, R.L. 1998. Multivariate data analysis, 5. Prentice Hall, Upper Saddle River, NJ, USA.

Hannan, M.T. and J. Freeman. 1984. Structural inertia and organizational change. American Sociological Review 49: 149-164.

Harford, J. 2005. What drives merger waves? Journal of Financial Economics 77(3): 529-560.

Hermans, F., F. Chaddad, T. Gagalyuk, S. Senesi and A. Balmann. 2017. The emergence and proliferation of agroholdings and mega farms in a global context. International Food and Agribusiness Management Review 20(2): 175-185.

Hirschberg, J. and J. Lye. 2001. The interpretation of multiple dummy variable coefficients: an application to industry effects in wage equations. Applied Economics Letters 8(11): 701-707.

Hockmann, H., R. Bokusheva and I. Bezlepkina. 2009. Agroholding membership: does it make a difference in performance. Quarterly Journal of International Agriculture 48(1): 25-46.

Kaul, A. and B. Wu. 2016. A capabilities-based perspective on target selection in acquisitions. Strategic Management Journal 37: 1220-1239.

Kim, J.J., J. Haleblian and S. Finkelstein. 2011. When firms are desperate to grow via acquisition: the effect of growth patterns and acquisition experience on acquisition premiums. Administrative Science Quarterly 56(1): 26-60.

Lapa, V., T. Gagalyuk and I. Ostapchuk. 2015. The emergence of agroholdings and patterns of land use in Ukraine. In: A. Schmitz and W.H. Meyers (eds.) Transition of agricultural market economies - the future of Kazakhstan, Russia and Ukraine. CABI, Wallingford, UK, pp. 102-110.

Lerman, Z., D. Sedik, N. Pugachov and A. Goncharuk. 2007. Rethinking agricultural reform in Ukraine. IAMO, Halle (Saale), Germany.

Li, Y. and X. Zhang. 2017. China's national balance sheet. Theories, methods and risk assessment. Springer, Singapore.

Liu, Q., R. Lu and L.D. Qiu. 2017. Foreign acquisitions and target firms' performance in China. The World Economy 40(1): 2-20. 
Maksimovic, V., G. Phillips and L. Yang. 2013. Private and public merger waves. The Journal of Finance 68(5): 2177-2217.

Markman, G.D. and W.B. Gartner. 2002. Is extraordinary growth profitable? A study of Inc. 500 high-growth companies. Entrepreneurship Theory and Practice 27(1): 65-75.

Matemilola, B.T., A.N. Bany-Ariffin and W.N.W. Azman-Saini. 2013. Impact of leverage and managerial skills on shareholders' return. Procedia Economics and Finance 7: 103-115.

Matyukha, A., P. Voigt and A. Wolz. 2015. Agro-holdings in Russia, Ukraine and Kazakhstan: temporary phenomenon or a permanent business form? Farm-level evidence from Moscow and Belgorod regions. Post-Communist Economies 27(3): 370-394.

Muehlfeld, K., U. Weitzel and A. van Witteloostuijn. 2011. Mergers and acquisitions in the global food processing industry in 1986-2006. Food Policy 36(4): 466-479.

Mueller, D. 1969. A theory of conglomerate mergers. Quarterly Journal of Economics 83: 643-659.

Nivievskyi, O. and O. Romanovska. 2013. Land reform barometer. World experience of land reform implementation: Russia. Institute of Economic Research and Policy Consulting, Issue No. 19/2013, Kyiv, Ukraine.

Nivievskyi, O., O. Stepaniuk, V. Movchan, M. Ryzhenkov and Y. Ogarenko. 2015. AGRICISTRADE country report: Ukraine. Institute of Economic Research and Policy Consulting, Kyiv, Ukraine.

Ostapchuk, I., A. Balmann and J. Curtiss. 2016. On perspectives and challenges of Ukrainian agroholdings: implications of the political and economic crisis. In: Land and Poverty Conference 2016: Scaling up Responsible Land Governance, Washington, DC, USA.

Palmer, D.A., P.D. Jennings and X. Zhou. 1993. Late adoption of the multidivisional form by large U. S. corporations: institutional, political, and economic accounts. Administrative Science Quarterly 38(1): 100-131.

Pasiouras, F., S. Tanna and C. Zopounidis. 2007. The identification of acquisition targets in the EU banking industry: an application of multicriteria approaches. International Review of Financial Analysis 16: 262-281.

Peng, M.W. and P.S. Heath. 1996. The growth of the firm in planned economies in transition: institutions, organizations, and strategic choice. The Academy of Management Review 21(2): 492-528.

Penrose, E. 1995. The theory of the growth of the firm, $2^{\text {nd }}$ edition. Oxford University Press, New York, NY, USA.

Petrick, M., J. Wandel and K. Karsten. 2013. Rediscovering the Virgin lands: agricultural investment and rural livelihoods in a Eurasian frontier area. World Development 41: 164-179.

Rosstat. 2019. Regions of Russia. Socio-economic indicators. Statistical yearbook. Rosstat, Federal Service of State Statistics, Moscow, Russian Federation.

Rylko, D. and R.W. Jolly. 2005. Russia's new agricultural operators: their emergence, growth and impact. Comparative Economic Studies 47: 115-126.

Salis, S. 2008. Foreign acquisition and firm productivity: evidence from Slovenia. World Economy 31(8): 1030-1048.

Serova, E.V. 2007. Agro-holdings: vertical integration in Russian agriculture. In: J.F.M. Swinnen (ed.) Global supply chains, standards and the poor: how the globalisation of food systems and standards affects rural development and poverty. CABI, Wallingford, UK, pp. 188-206.

Seth, A., K.P. Song and R. Pettit. 2000. Synergy, managerialism or hubris? An empirical examination of motives for foreign acquisitions of US firms. Journal of International Business Studies 31(3): 387-405.

Spark Interfax. 2019. Verification, analysis and monitoring of companies. Spark Interfax, London, UK.

Spearot, A.C. 2007. Firm heterogeneity, acqusition incentives, and trade liberalization. Working Paper, University of Wisconsin, Madison. WI, USA.

State Statistics Service of Ukraine (SSSU). 2019. Agriculture of Ukraine 2018. Statistical yearbook. SSSU, Kyiv, Ukraine.

Ukrainian Agribusiness Club (UCAB). 2011. Doing agribusiness in Ukraine 2011. UCAB, Kyiv, Ukraine. Available at: http://ucab.ua/files/Survey/Doing/doing_eng_2011.pdf

Ukrainian Agribusiness Club (UCAB). 2019. Large farm management book. UCAB, Kyiv, Ukraine. Available at: http://ucab.ua/en/lfm_book (in Ukrainian) 
Uzun, D., N. Shahaida and V. Saraykin. 2012. Russian agroholdings and their role in grain production (Агрохолдинги России и Их Роль в Производстве Зерна). Research on Agricultural Transition Policy No. 2012-2. FAO Regional Office for Europe and Central Asia, Budapest, Hungary. Available at: https://papers.ssrn.com/sol3/papers.cfm?abstract_id=2658003 (in Russian)

Uzun, V., N. Shagaida and Z. Lerman. 2019. Russian agriculture: growth and institutional challenges. Land Use Policy 83: 475-487.

Uzun, V., V. Bashmachnikov, E. Gataulina, V. Saraykin, G. Rodionova and O. Pavlushkina. 2008. Development trends and interaction mechanisms of small and large business in Russia's agriculture. In: Proceedings of A.A. Nikonov VIAPI, No. 24, Moscow, Russian Federation.

Verkhovna Rada of Ukraine. 2020. Law of Ukraine No. 552-IX 'On Amendments to Selected Laws of Ukraine on Turnover of Agricultural Lands'. Available at: https://zakon.rada.gov.ua/laws/show/552-IX (in Ukrainian)

Visser, O., N. Mamonova and M. Spoor. 2012. Oligarchs, megafarms and land reserves: understanding land grabbing in Russia. The Journal of Peasant Studies 39(3-4): 899-931.

Wandel, J. 2011. Business groups and competition in post-Soviet transition economies: the case of Russian 'agroholdings'. Review of Austrian Economics 24: 403-450.

Weche-Gelübcke, J.P. 2012. Foreign and domestic takeovers in Germany: cherry-picking and lemongrabbing. Working Paper Series in Economics, No. 240, Leuphana Universität Lüneburg, Institut für Volkswirtschaftslehre, Lüneburg, Germany.

Weche-Gelübcke, J.P. 2015. The impact of foreign takeovers: comparative evidence from foreign and domestic acquisitions in Germany. Applied Economics 47(8): 739-755.

Wegren, S.K. 2014. The Russian food embargo and food security: can household production fill the void? Eurasian Geography and Economics 55(5): 491-513.

YouControl. 2019. Business plan YouControl - a full profile of every business in Ukraine. YouControl, Kyiv, Ukraine. Available at: https://youcontrol.com.ua/en/ 
